\title{
Discussion on Construction Planning and Rainwater Control and Utilization Facilities under Background of Sponge City Construction in Loess Area
}

\author{
Liping Liu ${ }^{1,2}$, Wanfeng $\mathrm{Liu}^{1,2}$, Ping $\mathrm{Li}^{1,2}$, Hongping Yang ${ }^{1,2}$, Yan $\mathrm{Su}^{3}$ \\ ${ }^{1}$ School of Civil Engineering, Longdong University, Qingyang, Gansu, 745000, China \\ ${ }^{2}$ Provincial Key Laboratory of Loess Engineering Properties and Application in Universities, Qingyang, Gansu, 745000, China \\ ${ }^{3}$ Qingyang City Public Resources Trading Center, Qingyang, Gansu, 745000, China
}

\begin{abstract}
In view of the current construction practice of sponge city, effective rainwater system planning and rainwater control and utilization facility design are the key to give full play to its sponge function. Taking the sponge city construction of a city as an example, this paper explains the planning system, overall goal and planning strategy of the sponge city rainwater system, mainly discusses the design of storm-water control and utilization facilities, and carries out the sponge construction for the recently built and under construction projects as well as the demand of sponge construction, which plays an exemplary role for reference.
\end{abstract}

\section{Introduction}

The construction projects of a sponge city include building and community system construction project, garden and green space system construction project, road traffic system construction project, ecological restoration and gully protection tableland system project, drainage pipe network and storage facilities project, and smart sponge city system construction project. Sponge city concept are introduced to hope in drainage road runoff rainwater into the green belts in processing, but the geologic conditions for the collapsible loess, the water sensitivity is higher, roadbed instability, certainly will more strict with road anti-seepage treatment, Long Dong loess tableland belongs to typical geomorphic, due to long-term river cutting, table-land in gully, erosion gully head, form the tableland high deep valley, ravines crossbar.

\section{Sponge city construction planning system and overall objectives}

Sponge city construction should follow the principle of "source control, midstream storage and terminal discharge", combine their own conditions, and adopt measures of "seepage, stagnation, storage, net, use and discharge" according to local conditions, so as to minimize the impact of urban development and construction on the ecological environment, and realize $90 \%$ of local consumption and utilization of rainfall. Based on the comprehensive construction of sponge city in the city, a sponge construction measure system of "storage, net, use as the main, seepage, stagnation and drainage as the auxiliary" is finally established. "Storage, net, use primarily" is the core of sponge city construction in this city. The main features of sponge city construction are to strengthen the construction of water-saving, storage and regulation projects, ensure clean water quality, maintains water environment and water ecology.

Seepage, stagnation and drainage are the key to the construction of sponge cities. Seepage is an important measure to control the source of rainwater and reduce non-point source pollution in sponge city construction. Based on the comprehensive consideration of urban safety and collapsible loess characteristics, this paper puts forward that shallow and small infiltration facilities should be selected according to local conditions, and anti-infiltration measures should be taken according to site conditions to "moderate infiltration". Through "stagnation", the velocity of rainwater can be slowed down, the peak of runoff can be reduced, and urban water-logging can be alleviated from the source.

Sponge special planning of urban construction overall goal is to carry out the natural accumulation, natural penetration, natural purification sponge urban development concept, new area target oriented, has built area problem oriented, adjust measures to local conditions using "permeability, hysteresis, storage, net, with," measures such as perfecting the urban rainwater integrated management system, effective control of storm-water runoff, repair of urban water ecological, improve the water environment and water resources conservation and enhance its ability to prevent waterlogging, support "rain water, rain water-logging, water,

*Corresponding author's e-mail:635502138@qq.com 
not black smelly, heat island has alleviate" the realization of the goal, improve the quality of new urbanization, promote the construction of ecological civilization, and promote the harmonious development of man and nature, Build a green ecological city on the Loess Plateau.

\section{Planning Strategy of Rainwater System in Sponge City}

The planning strategy of sponge city rainwater system is to first establish a multi-stage rainwater collection and drainage-system, collect roof drainage and surface water collection, store water during rainfall, and release water during dry season. Secondly, the storage and regulation facilities according to local conditions should be adopted to increase the storage space of the site and enhance the flood resistance capacity of the park. Finally, the rainwater drainage system is combined with the transportation system, paving system and planting system to maximize the sponge effect of the site in the limited space. After planning to meet the relevant sponge city construction standards, it has truly achieved the "light rain no water, heavy rain no water-logging", effectively controlled urban non-point source pollution, realized the effective recovery and utilization of rainwater resources, and created a dry and wet planning in the limited space.

\section{$4 \quad$ Rainwater control and utilization facilities}

\subsection{Roof greening design}

Roof greening can be widely understood as all kinds of ancient and modern buildings, structures, city walls, Bridges (overpass) roof, terrace, roof, balcony or large artificial rockery on the mountain garden, plant trees and flowers collectively. Roof greening can increase the area of urban green space and improve the deteriorating space of human living environment. To improve the natural land and plants that have been replaced by the hard paving of many roads; To improve the harmful effects of excessive deforestation of natural forests, urban heat island effects caused by various waste gas pollution, sand storms and other hazards to human beings; It is of great significance to open up green space, build garden city, improve people's living conditions and living quality, beautify urban environment and improve ecological effect.

Roof greening is a way to save water, energy and land, but roof greening should be specially designed for specific roof load bearing and building characteristics, so as to meet the requirements of roof drainage plate in roof greening, such as light weight, easy handling, simple installation and stability. In addition, if the solar energy storage equipment has been installed, the roof greening should not adopt wall-climbing plants that may affect the operation of the electric panel due to their normal growth. At this time, some short upright flowers and plants can be simply arranged in the gap. In the absence of a solar roof, if the roof of the building is tilted at an Angle to the ground, it would be safer and more practical to let the vines cover the entire roof than to place pots and pots of grass directly on the roof. Schematic diagram of roof greening planting is shown in FIG.1.

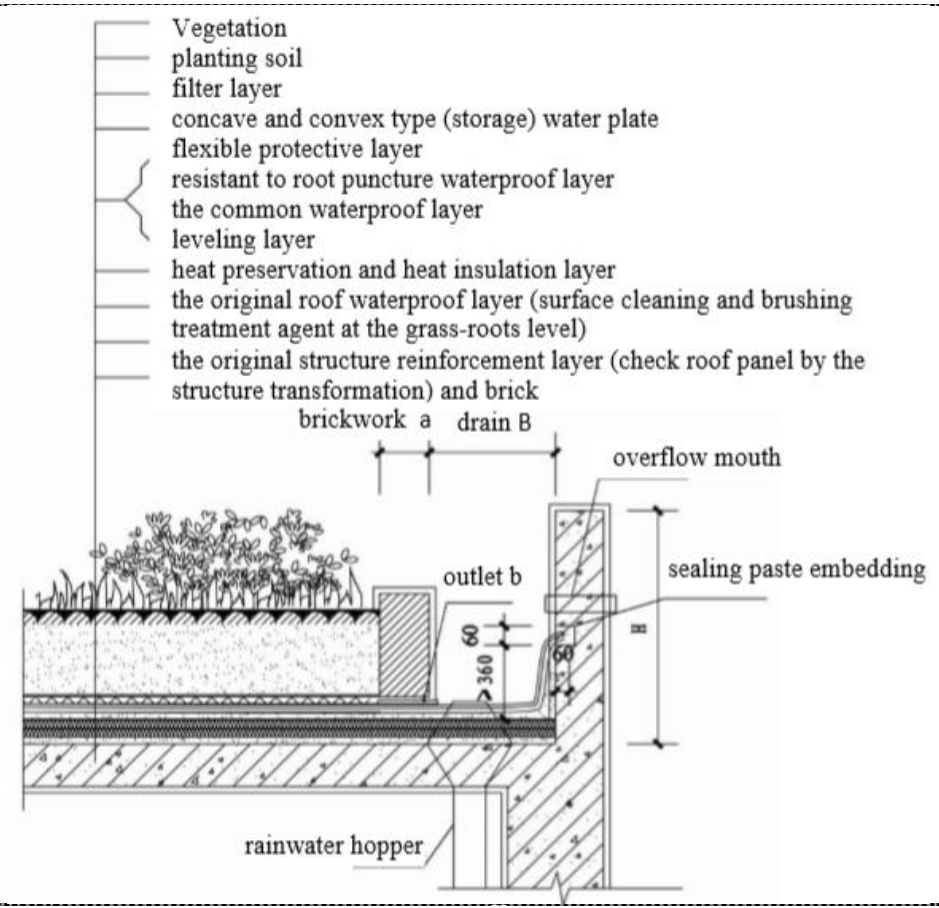

Figure 1. Scher rainwater hopper of roof greening planting. 
Building roof greening need to pay attention to the places as much as possible to take the local unique species, in addition to these species are more comfortable with the region's natural conditions, which can reduce the maintenance investment and economic considerations, and more importantly, local species for environment system itself is harmless, while artificial introduced species may cause species invasion and the collapse of the ecological system to a certain extent, it is completely against the idea of ecological architecture.

Under the premise of giving priority to local species, the roof greening system of buildings should also ensure a certain diversity of species. Diverse species can protect the living environment of the most basic organisms in the biological chain, guarantee the energy base of advanced organisms, and promote the healthy development of the ecosystem.

\subsection{Design of kerbstone inlet}

The kerb gap inlet should be set at the low point of the road and upstream of the rainwater inlet to intercept rainwater. The minimum spacing is $10 \mathrm{~m}$, which is reasonably determined according to the plane layout and the layout of rainwater facilities.

\subsection{Biological retention system}

Biological retention systems consist of soil layers and superficial vegetation (natural vegetation is preferred). The water meets through flows through the vegetation soil layer which has the filtration function enters the retention pond system, then transfers by the underground drainage system or naturally penetrates into the soil below the soil layer. Vegetation in the soil ACTS to trap pollutants, maintain water flow, solidify the soil, and control the rate at which water seeps into the soil. A retention system may be configured with a retention lowland or a long narrow marsh depression. In general, biogenic retention in lowlands is flat, while the bottom of biogenic marsh depressions can be somewhat sloping. The water depth above the surface of the soil layer is usually shallow.

Biological retention systems are used to clear a wide range of pollutants, such as suspended solids, maintenance trophozoites, metals, carbohydrates, and bacteria in rainwater runoff. If the system is designed with multistage and multifunctional aspects in mind, it can also be used as a diversified facility to reduce the peak flow rate and increase the permeability of rainwater.

Bioreactor systems can also be used to filter water from civil or non-civil sources. The total flow of water from drainage pipes or marsh depressions must be adequately protected against erosion and heat loss. The closer the bioreactor system is to the starting point of the water flow, the more effective it is. The system can handle water flow in different drainage areas within a single area in different sizes. The system can be installed in lawns, central areas, landscaped islands within parks, unused areas and certain specific areas.

The biological retention system can play a certain role only when it operates completely stably in the drainage area. Therefore, the implementation of the system must be carried out after the upstream water flow can move around the system and operate stably. The movement of water must be continuous and steady. The height design value relative to the seasonal high water level at the bottom of the system is at least $0.305 \mathrm{~m}$ lower than the biological retention bottom drainage system. For biological retention systems without bottom drainage, the seasonal high water design is at least $0.601 \mathrm{~m}$ below the vegetative soil. In addition, the existing soil beneath the biocurrent system is also important for the permeability of the water flow that can be adequately transmitted through the vegetation. The following figure 2 is between the schematic diagram of biological retention zone.

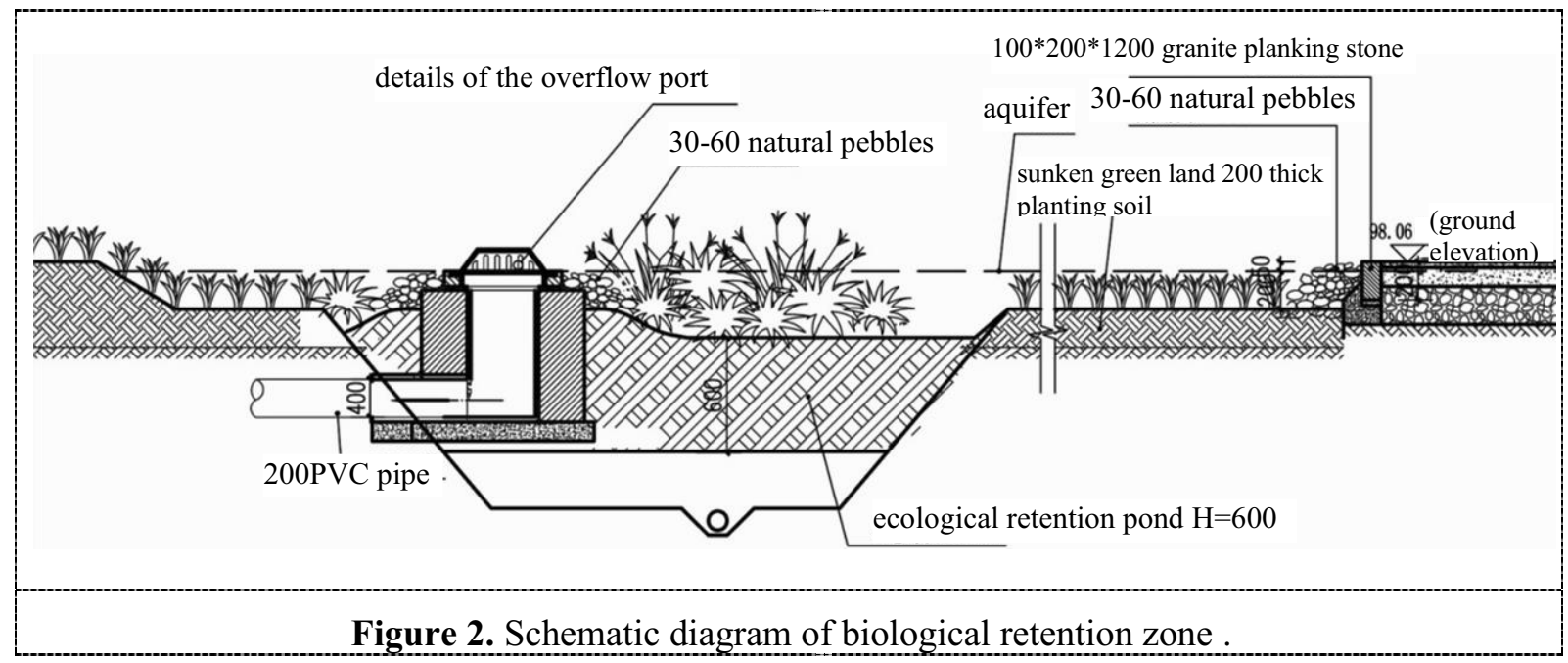

permeable asphalt concrete pavement according to the

\subsection{Permeable pavement in parking lot}

Permeable pavement can be divided into permeable brick pavement, permeable cement concrete pavement and different surface materials, and the cobbles and gravel pavement in grass-embedded brick and garden pavement also belong to permeable pavement. It is suitable for squares, parking lots, sidewalks and roads with less 
traffic flow and load, such as non-motorized driveway of building and community roads, municipal roads, etc. Pervious asphalt concrete pavement can also be used for motor vehicle lanes. Schematic diagram of permeable pavement in parking lot is shown in FIG.3.

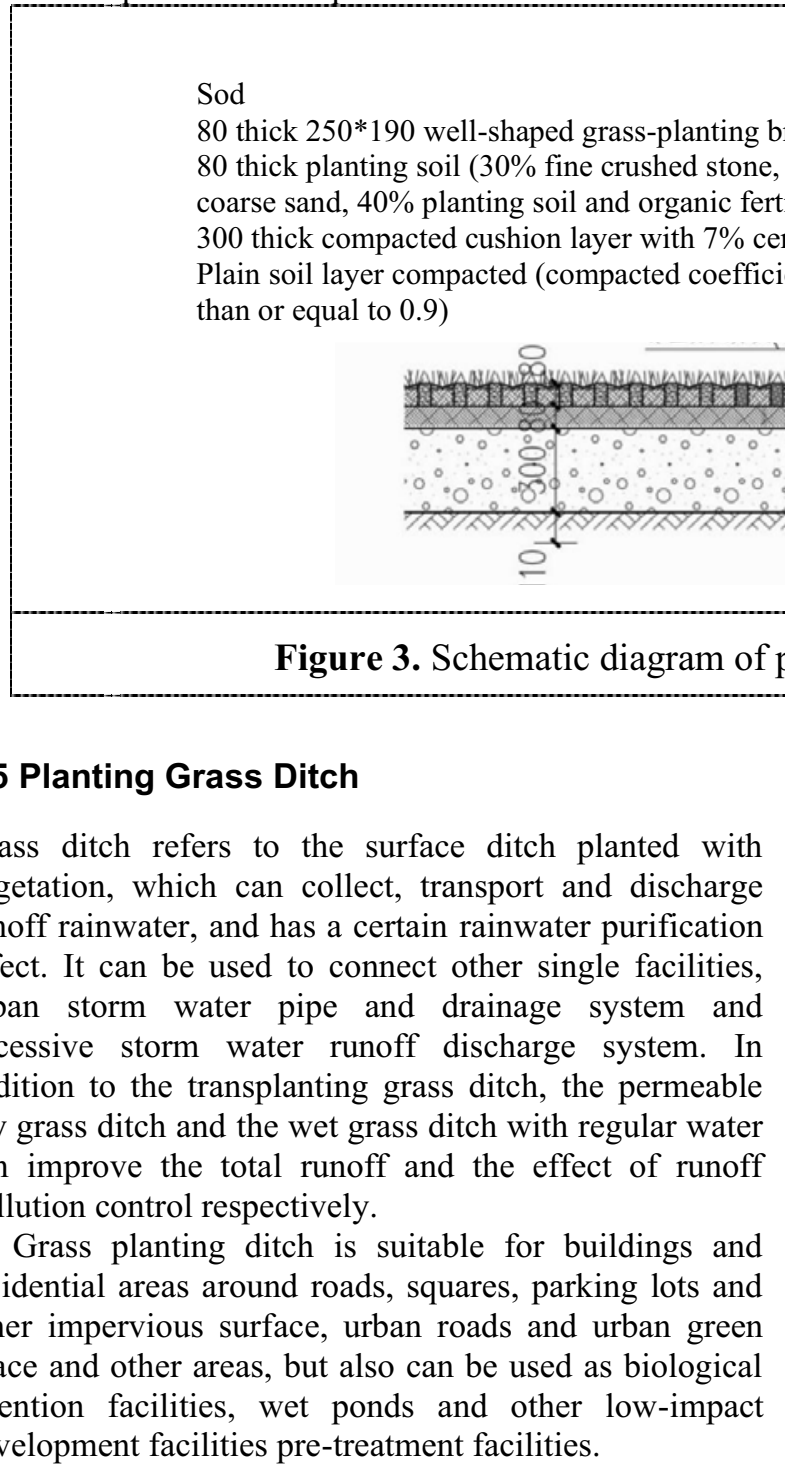

\section{6 drainage ditch}

Drainage ditch refers to the side ditch, cut ditch and subgrade nearby, cropland, residential low-lying area near the water collection to sub-grade, crop land, residential land other than the ditch.

The water level and section of the drainage ditch shall have sufficient carrying capacity and appropriate design water level. The design water level of the drainage ditch is divided into water-logging level and waterlogging level. The rehearsal water level is the level that the drainage ditch should maintain at ordinary times, which mainly meets the requirements of controlling groundwater. In order to ensure that the water level of agricultural ditch is not raised, bucket, branch, dry ditch drainage water-logging level should be reduced step by step, in addition to the longitudinal slope of the water flow, all levels of channel confluence still need to have an appropriate water level drop, generally 0.1 to $0.2 \mathrm{~m}$. Drainage water level, also known as the highest water level, is the water level when the drainage ditch is designed to flow through drainage. During water-logging drainage, the water level of all levels of gully should not be higher than the field elevation of both sides of gully, and $0.2-0.3 \mathrm{~m}$ lower than the field surface is appropriate. In the case of pumping and drainage, the drainage ditch section of the drainage pump or the drainage ditch section of small depressions shall be allowed to embankment water to make the water level in the ditch higher than the elevation of the two sides of the field. The section size of drainage ditch is determined by hydraulic calculation. The longitudinal slope of drainage trench bottom, the slope coefficient of cross section and the roughness of trench bed are selected first. The slope of drainage ditch is easy to collapse due to the outflow of underground water, so it often USES a slower slope. Because the drainage time is short, the gully slope is easy to grow grass, and the gully bed roughness is large, so the scour resistance is strong, so a steep longitudinal slope can be chosen.Schematic diagram of linear drainage ditch is shown in FIG.4. 


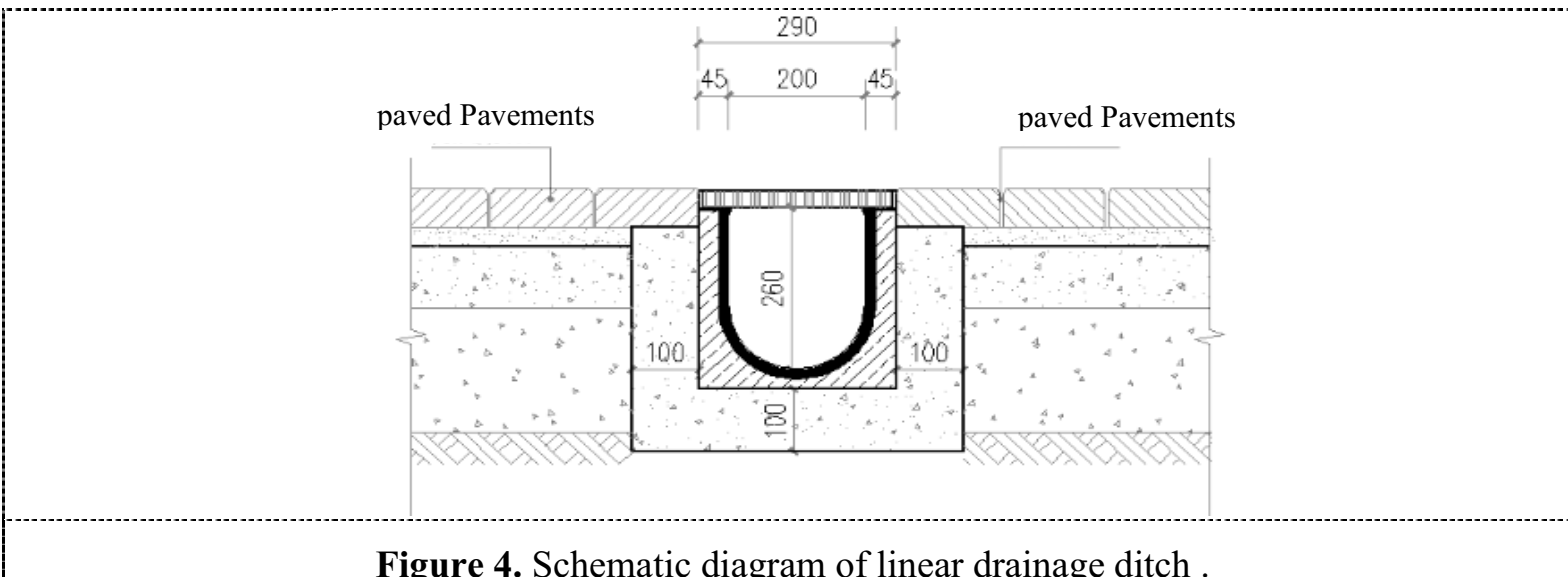

Figure 4. Schematic diagram of linear drainage ditch .

\section{Conclusion}

The rainwater control and utilization facilities of sponge city construction in loess region mainly transform the existing green belt into rainwater garden and sunken green space, so as to increase the amount of rainwater infiltration. The existing roof rainwater will be retained in the high flower beds through "breaking" measures, and part of the rainwater will be retained. The excess rainwater will overflow into the rainwater garden and sunken green space. The damaged hardened pavement in the building and park green space or community shall be transformed into permeable pavement, and the park green space or community parking lot shall be transformed into ecological parking lot. Through the vertical elevation design of the park green space or the road in the community, the drainage ditch beside the road is designed to concentrate the rainwater in the park green space or the community into the triangle green space. In order to retain more rain water, the triangle green space is changed into a rain pond to create an ecological and livable living environment with landscape design.

\section{Fund Project}

Research Project of Education and Teaching, Longdong University, Gansu, China. (2019-39).

Qingyang City Scientific and Technological Achievements Transformation Fund Project "AntiHydrophobic Technological Achievements Transformation, Promotion and Application". (FT2019-05).

\section{References}

1. Qiu Yanqun, Zhang Saiyan, Zhou Min. (2017) Application analysis of sponge city concept in urban water supply and drainage design. J. Standardization in China, 12: 140141.

2. Huang Jinyi. (2018) Urban drainage design exploration based on sponge city concept. J. Technological Innovation and Application, 28:88-89.

3. He Guichang. (2018) Introduction analysis of sponge city concept in the Design of a Commercial and residential Area. J. Building Materials and Decoration, 16:85-87.

4. Wang Yunlong. (2017) Annual Runoff Control Rate analysis of Sponge City -- A Case Study of Sponge City Planning in Qinhuangdao. J. Low-carbon World, 19:173-174.

5. Tang Kewang. (2016) Misunderstandings existing in sponge city construction. J. Water Resources Protection, 04:160-161.

6. Cui Guangbai, Zhang Qicheng, Zhan Zhongyu, Chen Yue. (2016) Research Progress of sponge city Construction and Discussion on some Issues. J. Water Resources Protection, 02:1-4

7. $\mathrm{Wu}$ Danjie, Zhan Shengze, Li Youhua, Tu Manzhang, Zheng Jianyang, Guo Yingyuan, Peng Haiyang. (2016) Research on the Emerging Trend and Practice of Sponge cities with Chinese characteristics. J. China Soft Science, 01:79-97. 